\title{
Integrative study of a new cold-seep mussel (Mollusca: Bivalvia) associated with chemosynthetic symbionts in the Marmara Sea
}

\author{
Bénédicte Ritt $^{\mathrm{a}, \mathrm{b}, \text { * }}$, Sébastien Duperron ${ }^{\mathrm{c}, \mathrm{d}}$, Julien Lorion ${ }^{\mathrm{e}}$, Cassandre Sara Lazar ${ }^{\mathrm{f}, \mathrm{g}}$, \\ Jozée Sarrazin ${ }^{\mathrm{a}, \text { * }}$
}

\author{
a Ifremer, Centre de Brest, DEEP/LEP, BP 70, 29280 Plouzané, France \\ b Biology Department, Temple University, BL 1900N 12th St., Philadelphia, PA 19122, USA \\ ${ }^{\mathrm{C}}$ Université Pierre et Marie Curie, Bâtiment A, 7 quai St Bernard, 75005 Paris, France \\ d UMR 7138 (UPMC CNRS IRD MNHN), Systématique, Adaptation, Evolution, 75005 Paris, France \\ e Japan Marine Science and Technology Center (JAMSTEC), Marine Ecosystems Research Department, 2-15 \\ Natsushima, Yokosuka 237-0061, Japan \\ ${ }^{f}$ Ifremer, Centre de Brest, DEEP/LM2E, BP 70, 29280 Plouzané, France \\ ${ }^{g}$ Department of Marine Sciences, University of North Carolina, Chapel Hill, NC, USA \\ *: Corresponding authors : Bénéditcte Ritt, +1 2152048858 ; fax: +1 2152046646 ; \\ email address : benedicte.ritt@temple.edu \\ Jozée Sarrazin, Tel.: +33198224329 ; email address : jozee.sarrazin@ifremer.fr
}

\begin{abstract}
:
Recently, small Idas-like mussels have been discovered living on carbonate crusts associated with cold-seeps in the Marmara Sea. These mussels, here referred to as Idas-like nov. sp., differ morphologically and genetically from another species identified as Idas aff. modiolaeformis, living in the same type of ecosystem in the Nile Deep-Sea Fan (eastern Mediterranean Sea). A phylogenetic analysis confirms the distinction between the two species, which belong to highly divergent lineages. Carbon stable isotope values, as well as the detection of thiotroph-related bacteria in the gill tissue, support the presence of a symbiotic, thiotroph-derived nutrition. In contrast, Idas aff. modiolaeformis displays six different types of symbionts. Finally our size-frequency data suggest that the recruitment is continuous in the examined area. The present study extends the documented distribution of symbiont-bearing mussels to the Marmara Sea, and contributes to the characterisation of biological communities in this recently explored area.
\end{abstract}

\section{Highlights}

First description of a thiotrophic mussel species discovered associated with cold-seep ecosystems in the Marmara Sea. Idas-like nov. sp. is morphologically different from Idas aff. modiolaeformis of the eastern Mediterranean Sea. Idas-like nov. sp. represents a new lineage in the Mytilidae tree. Both Idas species diverged a long time before both species colonised the Mediterranean Sea seeps.

Keywords : Mytilidae ; Idas-like Cold-seeps ; Marmara Sea ; Phylogeny ; Symbiosis ; Stable isotopes 


\section{Introduction}

Mytilid bivalves are ubiquitous metazoans in the marine environment, occurring from shallow waters to the abyssal zone in the oceans worldwide. Species exclusively observed in deepsea chemosynthesis-based ecosystems, such as hydrothermal vents, cold-seeps, and organic falls, were traditionally referred to the sub-family Bathymodiolinae Kenk and Wilson, 1985 (i.e. genera Bathymodiolus, Gigantidas, Tamu and Vulcanidas). The taxonomy of these deep mussels, however, is under discussion especially since the discovery of small AdipicolaDautzenberg, 1927 and IdasJeffreys, 1876 reported from cold-seeps and organic falls and classified within the sub-family Modiolinae (Lorion et al., 2009). Indeed, the monophyly of the Bathymodiolinae clade is no longer supported by molecular results (Samadi et al., 2007), which suggest that (1) the Bathymodiolinae are rooted within the Modiolinae Keen, 1958; and (2) the symbiont-bearing mussels are monophyletic mussels within the family Mytilidae ( [Kenk and Wilson, 1985], [Duperron et al., 2007], [Miyazaki et al., 2010] and [Von Cosel and Marshall, 2010]). Thus, we consider it more convenient to refer to the Marmara Sea mussels as Idas-like due to their similaritieswith small symbiont-bearing species assigned to the Idas genus (sensu stricto) that have been previously reported from vents, seeps and organic falls. The purpose of this study is not to re-evaluate the classification of mytilids but to describe the new species found in Marmara cold seeps and the identity of its symbionts.

At vents and seeps, bivalves occur in dense beds and their distribution patterns appear to be strongly related to substratum types and chemical gradients (particularly methane and sulphides, see reviews in [Duperron et al., 2009], [Levin, 2005] and [Sibuet and Olu, 1998]). Their adaptations to these extreme environments, which are inhospitable to many other invertebrates because of low oxygen and high hydrogen sulphide concentrations, include their association with symbiotic bacteria. These symbionts are localised in gill tissues, use diverse carbon sources and derive their energy from the oxidation of reduced compounds present in the fluids emitted at the seafloor ( [Felbeck et al., 1981], [Cavanaugh, 1983], [Fisher, 1990] and [Duperron, 2010]). To date, the most frequent types of associations within symbiont-bearing mussels involve thiotrophic (sulphur-oxidising: SOX) and methanotrophic (methane-oxidising: MOX) bacteria (see reviews in [Dubilier et al., 2008] and [Duperron et al., 2009]).

Symbiont-bearing mussels from deep-sea chemosynthetic ecosystems have been intensively studied. Phylogenetic studies suggest that organic falls served as "stepping-stones" allowing the shallow ancestors to colonise deep-sea vents and cold-seeps ( [Distel et al., 2000], [Samadi et al., 2007], [Lorion et al., 2009] and [Lorion et al., 2010]). Although stimulating, this hypothesis is still debated, in particular because of a sampling bias, as very few species associated with organic falls were investigated compared to those from vents and seeps (Lorion and Samadi, 2010). Authors are 
also faced with nomenclatural issues arising from early species descriptions, which where based on morphological shell characters from few individuals and published before the advent of molecular methods. Moreover, some common features found in mollusc taxa, such as allometric growth, environmental plasticity and crypticism, were not often taken into account (Baker et al., 2003; Von Cosel and Olu, 1998; Won et al., 2003). Therefore, the use of anatomical characters alone introduced some ambiguities in the definition of species and even genera.

In spite of these difficulties, new symbiont-bearing mussel species are regularly sampled and described from different deep-sea ecosystems. A recent study of a small mussel from cold-seep sites in the eastern Mediterranean Sea, tentatively attributed to Idas modiolaeformis, indicated that it occurred in low densities, mostly associated with carbonate crusts while its close relatives were associated with sunken organic remains (Duperron et al., 2008b; Lorion et al., 2012). Unexpectedly, this Idas aff. modiolaeformis was shown to harbour six types of symbionts including sulphur- and methane-oxidising bacteria, representing the highest diversity of symbionts reported in mussels so far. These results suggest that mytilids can associate with a wider diversity of bacteria than previously thought (Duperron, 2010). More recently, a global re-assessment of deep-sea mussels using molecular tools has been initiated with the addition to the Mytilidae tree of 25 mussel species from organic falls in the Pacific Ocean (Duperron et al., 2008a; Lorion et al., 2010; Lorion et al., 2009). These studies highlighted the complexity and multiplicity of colonisation events among vents, seeps and organic falls and substantially challenge earlier hypotheses. Their conclusions emphasise the fact that the history of the whole group is still poorly understood. 
115 During the MarNaut cruise (2007), the exploration of new cold-seep sites in the deep

Marmara Sea, the easternmost semi-enclosed basin of the Mediterranean Sea, led to

117

the collection of new Idas-like mytilid specimens, referred to herein as Idas-like nov. sp. This Marmara Sea mytilid species presented similarities with Idas aff. modiolaeformis from the eastern Mediterranean in terms of colonised substratum (carbonate crust), depth range (between 1000-2000 m) and morphology. Hence, in this study, we aimed at determining: (1) whether the mussel sampled in the Marmara Sea is the same species as Idas aff. modiolaeformis recently collected in the eastern Mediterranean Sea, (2) how these two species are related, and, (3) whether they have a similar group of symbiotic bacteria. Mussel morphology and symbiont type were characterised using morphological, microscopic and molecular methods. Carbon-nitrogen stable isotope compositions of tissues were also investigated to estimate the contribution of bacterial symbionts to the host's nutrition. The present study extends the documented distribution of symbiont-bearing mussels to the Marmara Sea, and contributes to the characterisation of biological communities in this recently explored area.

\section{Material and methods}

\subsection{Sampling site, animal collection and specimen preservation}

The mytilid bivalves were collected in June 2007 at a cold-seep site in the north-east Central Basin of the Marmara Sea $\left(40^{\circ} 51.27^{\prime} \mathrm{N}-28^{\circ} 10.19^{\prime} \mathrm{W}\right.$, Figure 1) at a depth of $1120 \mathrm{~m}$ using the manned submersible Nautile deployed from the R/V l'Atalante. This cold-seep site was characterised by upward fluid flows and carbonate crust 
139 precipitations forming outcrops where mussel beds were observed (Ritt et al., 2010).

140 During dive 1665, three fragments of carbonate crusts (CC1, CC2 and CC3, see

141 details in Ritt et al. (2010)) were sampled. The fauna was removed from the crusts and 220 mussels were fixed for a variety of analyses (Table 1). Tube cores $(30 \mathrm{~cm}$

143 long, $5.4 \mathrm{~cm}$ inner diameter) were also taken in reduced sediments $(\mathrm{n}=3)$ located a

144 few meters away from the sampled carbonate crust for carbon and nitrogen stable 145 isotope analyses of the sedimented organic matter (SOM). In the laboratory, the lengths and heights of 217 unbroken mussel shells were measured according to Kenk and Wilson (1985). The total preserved wet weight (shell + tissue) was also measured for 207 individuals (including only individuals preserved in formalin and

149 alcohol, not the frozen ones). Moreover, two additional specimens were also sampled on carbonate crusts from a second location explored during dive 1644 on the western slope of the Tekirdağ Basin $\left(40^{\circ} 50^{\prime} \mathrm{N}-27^{\circ} 30^{\prime} \mathrm{E}\right)$ at $1068 \mathrm{~m}$ depth (Figure $\left.1 \mathrm{~A}\right)$. These individuals were used for DNA extraction to determine whether one or several species could occur in the different basins of the Marmara Sea. To complete our study, we used 72 individuals that were sampled in the eastern Mediterranean Sea during the NAUTINIL cruise (2003) at $2130 \mathrm{~m}$ depth in the Nile Deep-Sea Fan (NDSF, Figure 1B; $\left.32^{\circ} 38.4^{\prime} \mathrm{N}-2^{\circ} 55.0^{\prime} \mathrm{E}\right)$, a site described in Bayon et al. (2009) and by Lorion et al. (2012) were measured in the same way as those from the Marmara Sea. 


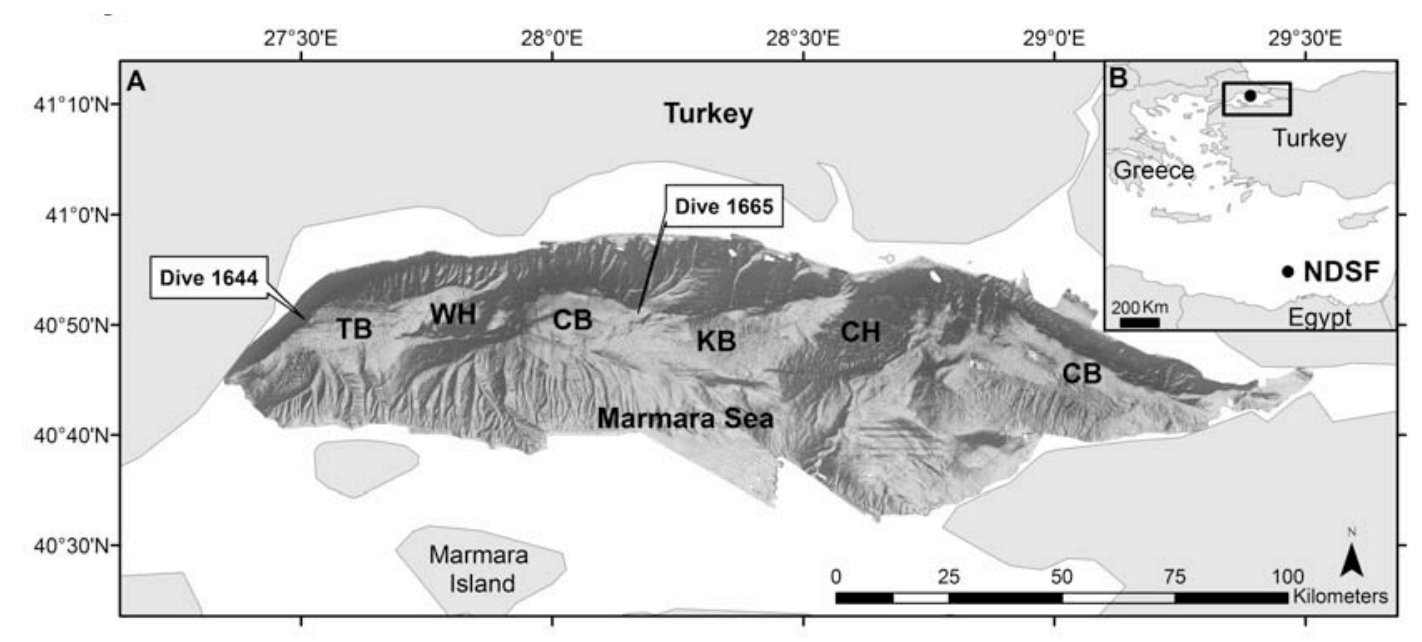

Figure 1. (A) The Marmara Sea showing the succession of the different basins and the location of the dives 1644 and 1665 during the MarNaut cruise (2007). (B) General map of the eastern Mediterranean Sea with the sampling sites (black dots) in the Nile Deep-Sea Fan (NDSF) explored during the NAUTINIL cruise (2003) and the Marmara Sea. Abbreviations from west to east: TB, Tekirdağ Basin; WH, Western High; CB, Central Basin; KB, Kumburgaz; CH, Central High: Basin CB, Çinacik Basin.

\subsection{Morphology and morphometry}

163 The morphology of the sampled mussels was examined and compared with descriptions of the seven species from the genus ldas reported from the Mediterranean Sea and Atlantic Ocean, namely Idas argenteus Jeffreys, 1876; Idas modiolaeformis Sturany, 1896; Idas simpsoni (Marshall 1900); Idas dalmasi

167 Dautzenberg, 1927; Idas ghisotti Warén and Carrozza, 1990 Idas macdonaldi 168 Gustafson et al. (1998) and Idas cylindricus Pelorce and Poutiers, 2009. Type specimens of Idas simpsoni, Idas ghisotti and Idas cylindricus and specimens of Idas aff. modiolaeformis studied by Duperron et al. (2008b) and Lorion et al. (2012) were also available for direct comparison.

173 Size (length) frequency distribution was analysed to determine the different 174 distribution modes that might correspond to different settlement events 175 (Bhattacharya, 1967). In this analysis, the magnitude of size classes was chosen so 
that at least 30 individuals cluster in the main classes (i.e. with the highest number of individuals). Thus, the class-sizes were delimited according to an interval of $1 \mathrm{~mm}$ for Idas-like nov. sp. and $2 \mathrm{~mm}$ for Idas aff. modiolaeformis.

To test for the effect of preservation method on mussel biomass, a non-parametric Mann-Whitney $U$ test was performed on average wet weights between mussels preserved in alcohol $(n=55)$ and formalin $(n=152)$.

\section{Table 1}

Collection information as well as number of individuals and preservation type for each analysis performed in this paper. Abbreviations: $A_{70}$ or $A_{96}=$ alcohol $70 \%$ or $96 \%$ respectively, $\mathrm{F}_{10}=$ formalin $10 \%, \mathrm{Fz}=$ frozen at $-80^{\circ} \mathrm{C}, \mathrm{FISH}=$ properly prepared for Fluorescence In Situ Hybridization analyses, TC= top layer of Tube Core.

\begin{tabular}{|c|c|c|c|}
\hline Year & 2003 & 2007 & 2007 \\
\hline Cruise-dive \# & Nautinil-1551-1553 & Marnaut-1644 & Marnaut-1665 \\
\hline Sample reference & & R4 & CC1-2-3, BioBox \\
\hline Morphometry & 72 & & 217 \\
\hline Host phylogeny & & $2 \mathrm{Fz}$ & $2 \mathrm{Fz} / 1 \mathrm{~A}_{96}$ \\
\hline Symbiont diversity & & & $1 \mathrm{Fz}$ \\
\hline FISH analyses & & & $\begin{array}{c}1 \mathrm{~A}_{70} \rightarrow \text { Ind. } \mathrm{A} \\
1 \mathrm{FISH} / \mathrm{Fz}\end{array}$ \\
\hline Stable isotopes & & & $3 \mathrm{Fz} / 3 \mathrm{TC}$ \\
\hline Biomass & $60 F_{10}$ & & $152 F_{10} / 55 A_{70}$ \\
\hline Total of individuals & 83 & 2 & 220 \\
\hline
\end{tabular}

The relationships between length $(L)$, mass $(M)$, and height $(H)$ were estimated by fitting coefficients $a$ and $b$ in a power function, $Y=a(X)^{b}$ where $X$ is the length and $Y$ is alternatively the mass or the height (Huxley and Teissier, 1936). For $b=3$, it is supposed that the growth is isometric, meaning that the growth in length occurs at the same rate as the growth in height or mass. Size-mass relationships were compared between sampling locations using non-parametric Mann-Whitney $U$ test to detect differences in the average biometric measurements (length, height, weight). Finally, significance of the regression coefficient $\left(R^{2}\right)$ between log-transformed [ $\log$ (L) versus $\log (M)$ or $\log (H)]$ measurements was also tested. 
DNA was extracted from gills of one specimen for the symbiont analyses, and from foot tissue of 5 specimens for the host analyses (Table 1) using the QIAamp ${ }^{\circledR}$ DNA Micro Kit (Qiagen). For mussel taxonomy and phylogeny, DNA was extracted from foot tissue to avoid the risk of sequencing paternal lineages, which are concentrated in the gonads for those taxa. Fragments of the Cytochrome Oxidase subunit I mitochondrial gene (COI mtDNA) and of the $28 \mathrm{~S}$ rRNA nuclear gene were amplified as described in Lorion et al. (2010). For symbiont characterisation, prokaryotic $16 \mathrm{~S}$ rRNA was amplified according to protocols described in Duperron et al. (2005) including the application of 25 PCR cycles to minimise PCR biases. PCR and cloning products were purified and sequenced in both directions at the Genoscreen facility (Lille) and chromatograms were edited using Sequencher 4.1.4 (Gene Codes Co.).

\subsubsection{Host taxonomy and phylogeny}

210 Sequences of the Idas-like nov. sp. were added to the COI dataset \#3 and 28S dataset \#4 analysed by Lorion et al. (2010), which are representative of all symbiontbearing mussel lineages currently known. The datasets obtained were aligned and K2P genetic distances were calculated with Mega 4 (Tamura et al., 2007). Phylogenetic relationships were inferred from the combined dataset using the Bayesian approach implemented in the Beast 1.5.4 package (Drummond and Rambaut, 2007). The Yule speciation model was used as a tree prior and heterogeneity of mutation rates across lineages was set under an uncorrelated lognormal relaxed clock. A Generalised Time Reversible (GTR) model with a gamma 
law ( $\mathrm{C}$, four categories) and a proportion of invariants (I) was used for both genes and adjusted with respect to data partition. The mutation rate was set to 1 to get branch lengths in units of substitution per site. The tree was rooted on Modiolus modiolus according to Samadi et al. (2007). Four parallel analyses starting from distinct coalescent trees were run over 20 million generations and sampled each 1000 steps. After analysing the results with Tracer v1.4.1 and discarding the first $50 \%$ of the samples as a burn-in, independent runs were pooled and resampled each 4000 steps. The maximum clade credibility tree was drawn from these pooled results (10,000 samples). Posterior probabilities of its nodes and mean branch lengths were calculated from the rest of trees (i.e. all Bayesian trees sampled after posterior distribution reached stationary).

\subsubsection{Symbiont characterisation}

The 16S rRNA sequences were compared to sequences available in databases using the BLAST search program (http://blast.ncbi.nlm.nih.gov/Blast); (Altschul et al., 1990), aligned with the SINA Web Aligner (Pruesse et al., 2007) and edited in the BioEdit v7.0.5 programme (Hall, 1999). Phylogenetic trees were estimated using the Maximum Likelihood heuristic search using the PHYLIP software (Felsenstein, 1989). Rarefaction curves were calculated for the 16S rRNA clone library using the RarFac programme (http://www.icbm.de/pmbio) and gene library coverage was calculated using the following formula: $C=\left[1-\left(n_{1} / M\right)\right] \times 100$, where $n_{1}$ is the number of unique OTUs and $N$ the number of clones in the library (Singleton et al., 2001). Sequences from different symbiont types observed in other mussels from the literature have been included in our dataset, including those associated with Idas aff. modiolaeformis from the eastern Mediterranean Sea (Duperron et al., 2008b). 
2.4. Fluorescence in situ hybridisation

Two mussels from carbonate crust CC3 were dissected. One (individual A, Table 1) had been fixed in unbuffered $10 \%$ formalin, naturally buffered by the carbonates, and transferred after $48 \mathrm{~h}$ in $70 \%$ alcohol. Another (individual B, Table 1) had been frozen and stored several months before post-fixation of the gills for FISH analyses (2 hours

250 in unbuffered $4 \%$ formalin, two washes in $1 \mathrm{X}$ phosphate-buffered saline (PBS), and storage in PBS:ethanol 1:1). Gill fragments were dehydrated in increasing ethanol series and embedded in polyethylene glycol disterate: hexadecanol-1 (9:1) wax. 10 $\mu$ m-thick transverse sections were cut with a microtome (Jung, Germany) and 254 collected on SuperFrost Plus slides. The wax was removed with ethanol and samples 255 were rehydrated in decreasing ethanol series. Hybridisations were performed for 3 hours at $46^{\circ} \mathrm{C}$ as described previously using a hybridisation buffer containing $30 \%$ formamide (5M NaCl, $1 \mathrm{M}$ Tris- $\mathrm{HCl} 20 \%$ SDS, 30\% formamide in (Duperron et al., 2008b). Seven oligonucleotide probes were used to test the presence of different bacterial groups (Table 2). Probes were labelled with Fluoresceine (FITC), Cyanine Cy3 or Cyanine Cy5. The general bacteria probe EUB338 was used as a positive control. After hybridisation, slides were washed $(5 \mathrm{M} \mathrm{NaCl}, 1 \mathrm{M}$ Tris- $\mathrm{HCl}, 0.5 \mathrm{M}$ EDTA, $20 \%$ SDS) at $48^{\circ} \mathrm{C}$ for 15 minutes, rinsed with MilliQ water, and mounted in a SlowFade medium. Sections were observed under an epifluorescence microscope 264 (Olympus, Japan). 


\section{Table 2}

Oligonucleotide probes used in this study. The position in the 16S rRNA gene of Escherichia coli is given.

\begin{tabular}{|l|l|c|l|l|}
\hline Probe & Sequence (5' $\mathbf{~ 3 '}^{\prime}$ ) & Position & Target & References \\
\hline EUB-338 & GCTGCCTCCCGTAGGAGT & 338 & Most eubacteria & Amann et al., (1990) \\
\hline Bthio-193 & CGAAGATCCTCCACTTTA & 193 & Thiotrophic bacteria & Duperron et al., (2007) \\
\hline BangT-642 & CCTATACTCTAGCTTGCCAG & 642 & Thiotrophic bacteria & Duperron et al., (2005) \\
\hline EPY-549 & CAGTGATTCCGAGTAACG & 549 & Epsilonproteobacteria & Manz et al., (1992) \\
\hline CF-319 & TGGTCCGTGTCTCAGTAC & 319 & Bacteroides & Manz et al., (1996) \\
\hline GAM-42 & GCCTTCCACATCGTTT & 42 & Gammaproteobacteria & Manz et al., (1992) \\
\hline ImedM-138 & ACCATGTTGTCCCCCACTAA & 138 & Methanotrophic bacteria & Duperron et al., (2008b) \\
\hline BangM-138 & ACCAGGTTGTCCCCCACTAA & 138 & Methanotrophic bacteria & Duperron et al., (2005) \\
\hline
\end{tabular}

2.5. Stable isotope analyses

272 Nitrogen and carbon stable isotope signatures were measured in soft tissue of three

273 individuals, and in the $0-1 \mathrm{~cm}$ layer of three tube core samples (Sedimented Organic

274 Matter, SOM). According to the small size of the animals, the whole soft tissues of

275 the frozen mussels (Table 1) were lyophilised overnight and homogenised in a fine powder using a mortar and pestle. Sediment samples were treated as described in

277 Carlier et al. (2010). All samples were analysed at ISO-Analytical Laboratory

278 (Cheshire, UK) using the elemental analysis-isotope ratio MS method. The isotopic composition was expressed as the relative difference between isotopic ratios in the sample and that in conventional standards, PDB (Pee Dee Belemnite) for carbon and air $\mathrm{N}_{2}$ for nitrogen as follows:

282

$\delta^{13} \mathrm{C}$ or $\delta^{15} \mathrm{~N}(\% \circ)=\left[\left(\mathrm{R}_{\text {sample }} / \mathrm{R}_{\text {standard }}\right)-1\right] \times 1000$ where $\mathrm{R}={ }^{13} \mathrm{C} /{ }^{12} \mathrm{C}$ or ${ }^{15} \mathrm{~N} /{ }^{14} \mathrm{~N}$.

3. Results

3.1. Morphological description 
The shells of all 220 Idas-like mussels from the Marmara Sea were modioliform, smooth, yellow to brown in colour, and devoid of periostracal hair unlike Idas modiolaeformis (Figures 2A, C, E). Morphological variability was observed on the ventral margin, which was occasionally straight (Figure 2C), but most of the time curved with an inflexion point in the middle of the ventral margin (Figure $2 \mathrm{C}$ ). The anterior was usually narrower than the posterior. Antero-posterior lengths ranged from 5.2 to $20.8 \mathrm{~mm}$ (mean $15.5 \pm 3.2 \mathrm{~mm}$ ) and heights varied between 2.8 and 10.1 $\mathrm{mm}$ (mean $7.5 \pm 1.5 \mathrm{~mm}$ ). The boundary of the inhalant siphon was smooth (not shown).

Idas-like nov. sp. differed markedly from most described Mediterranean and Atlantic species, namely Idas argenteus, Idas simpsoni, Idas dalmasi, Idas ghisotti and Idas cylindricus, in having a modioliform shell shape, thick and dark brown periostracum, and no periostracal hair. These characters and the occurrence of a fringe on the boundary of the inhalant siphon (not shown) of specimens studied by Duperron et al. (2008b) and Lorion et al. (2012) has also allowed the distinction between Idas-like nov. sp. and Idas aff. modiolaeformis. However, shell morphology of Idas-like nov. sp. (Figures 2A, C, E) was very close to that of the large type specimen of Idas modiolaeformis described by Sturany (1896).

One post-larval shell, observed by SEM, was $450 \mu \mathrm{m}$ in diameter (prodissoconch II stage, Figure 3A). The shell exhibited concentric lines except near the umbo, which is a granulated structure corresponding to the prodissoconch I stage (Figure 3B). 


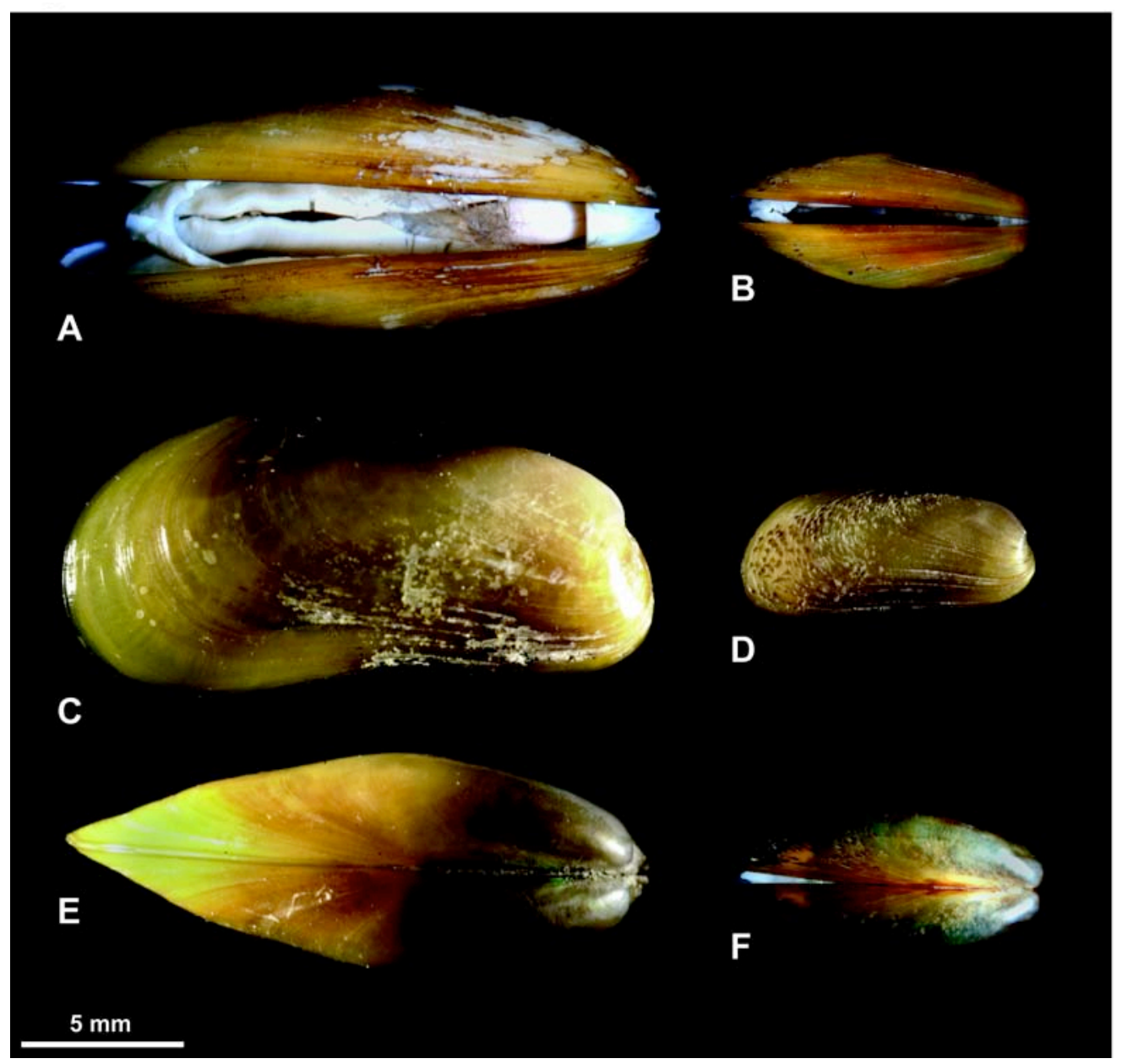

Figure 2. Photographs of external views of the mytilid ldas-like nov. sp. (A, C, E) and Idas aff. modiolaeformis from the eastern Mediterranean Sea $(B, D, F)$ : ventral view $(A, B)$, right valve $(C, D)$, and dorsal view $(E, F)$. All specimens were sampled during the MarNaut (2007) and NAUTINIL (2003) cruises.
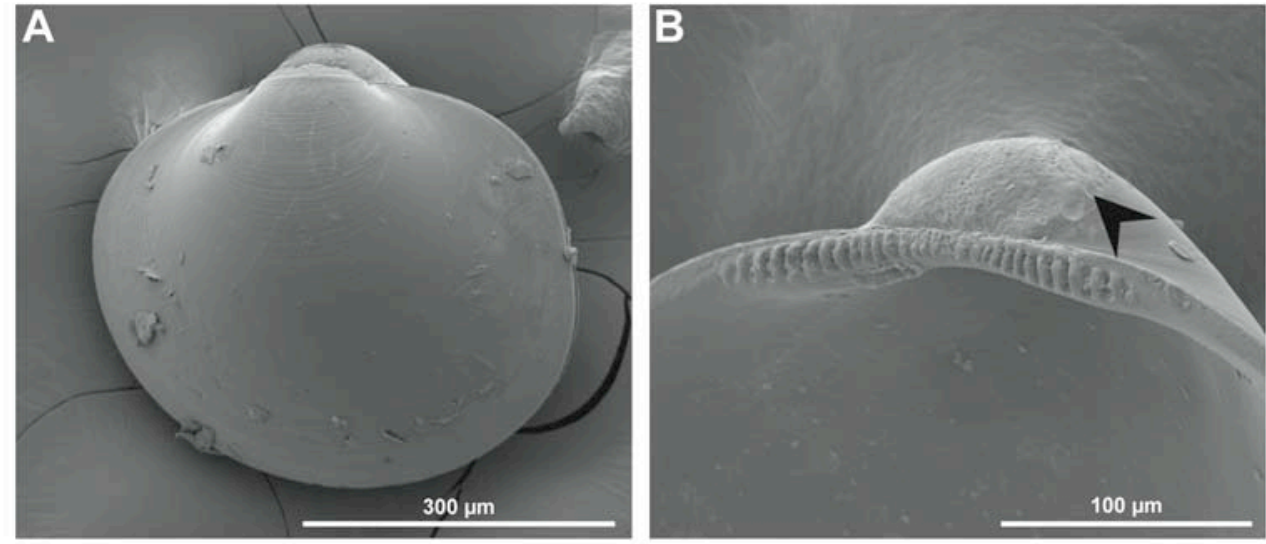

Figure 3 Scanning electron microscope imagery of (A) the prodissoconch II of a larvae sampled from sediments during the MarNaut cruise (2007) and (B) details of the hinge, the boundary between the prodissoconch I and prodissoconch II (black arrow). 
313 Size-frequency distributions of both Idas-like nov. sp. and Idas aff. modiolaeformis 314 displayed a unimodal structure (Figure 4). In Idas-like nov. sp., the most abundant size class was 17-18 mm (Figure 4), whereas smaller specimens (4-6 mm, Figure 4) dominated the distribution in Idas aff. modiolaeformis. Specimens of Idas from the eastern Mediterranean Sea were significantly smaller in length $(5.5 \pm 1.8 \mathrm{~mm})$ and height $(2.7 \pm 0.9 \mathrm{~mm})$ than those from the Marmara Sea with a mean shell length of $15.5 \pm 3.2 \mathrm{~mm}$ and a mean shell height of $7.5 \pm 1.5 \mathrm{~mm}$ (Mann-Whitney test on shell length, $W=15365, p<0.05$; height, $W=17573, p<0.05)$. According to length-height relationships (Figure $5 \mathrm{~A}$ ), the shell height increased more slowly than the cube of the shell length during the growth in both groups (b<3; Table 3).

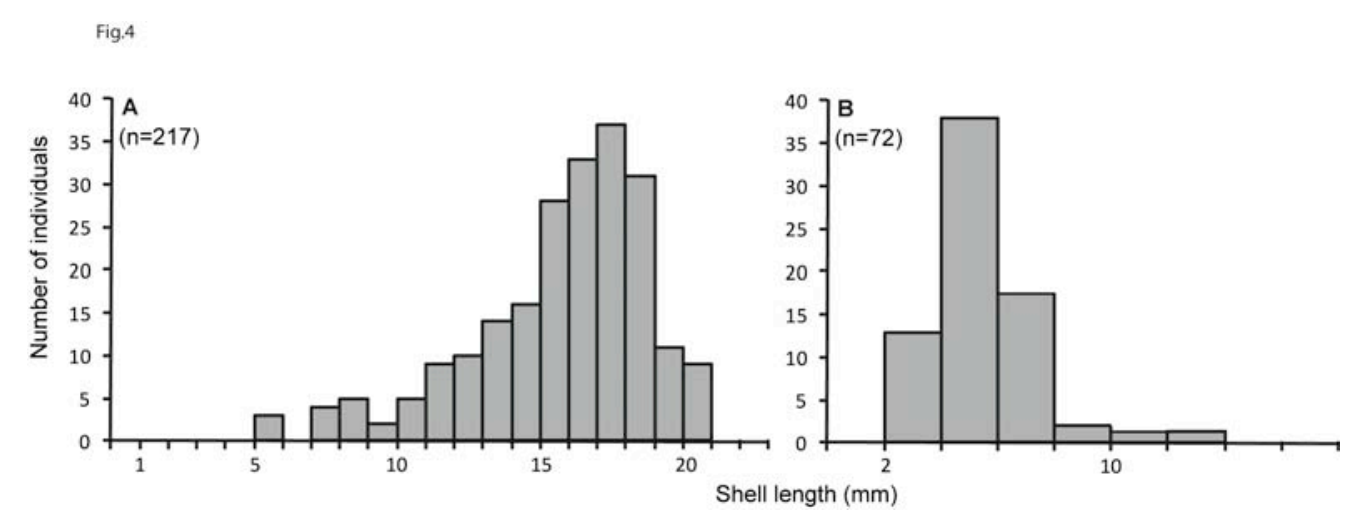

Figure 4. Length frequency distribution of (A) Idas-like nov. sp. sampled in June 2007 and (B) Idas aff. modiolaeformis from the eastern Mediterranean Sea sampled in September 2003. $n=$ sample size.

There was no significant difference (Mann-Whitney, $\mathrm{W}=4048, p=0.73$ ) between total wet biomass measures of specimens preserved in alcohol $(n=55)$ or formalin $(n=152)$. Thus, the length-mass relationship was analysed using all individuals from 

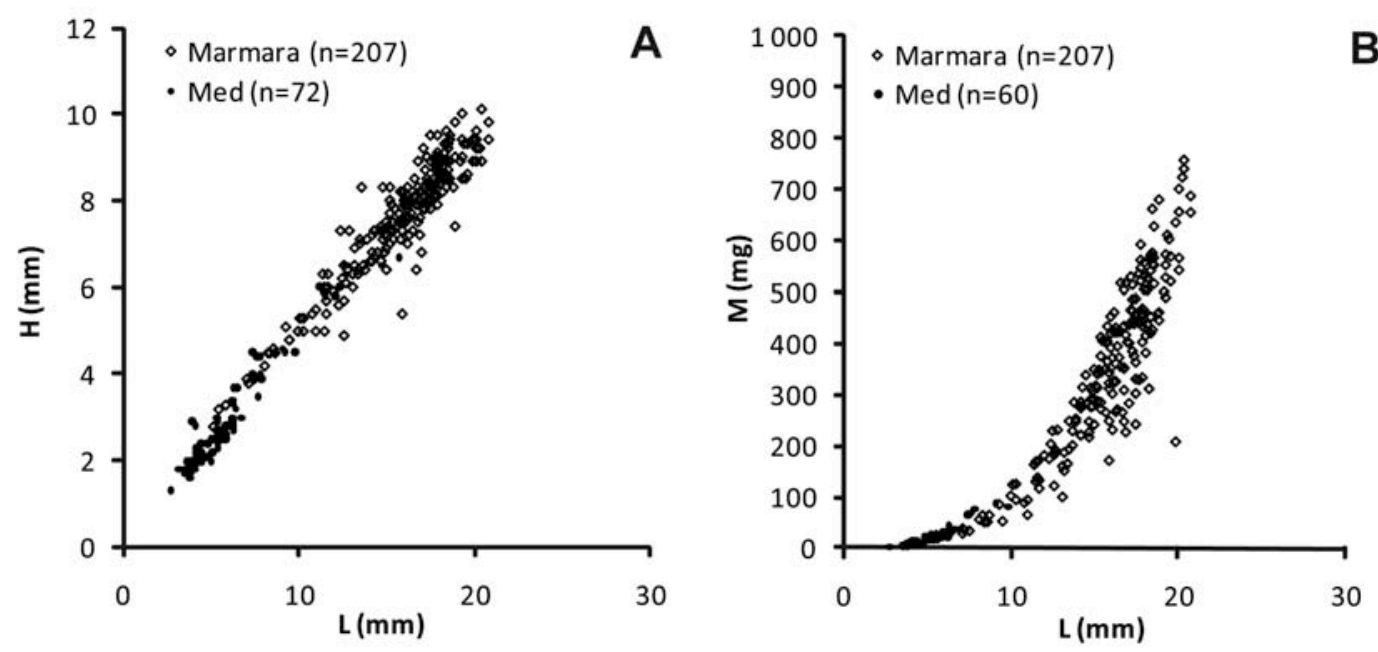

Figure 5. (A) Length-height and (B) length-mass relationships for the Idas-like nov. sp. (light diamonds) and Idas aff. modiolaeformis (black circles) from the eastern Mediterranean Sea. Total preserved wet biomass indicates total animal biomass (shell + tissue). The relation used is $Y=a(X)^{b}$ where $Y$ is the height of the mass and $X$ is the length. The relations with the parameters $a, b$ and $R^{2}$ and all relationships are significant with $p<0.001$.

\section{Table 3}

Summary of the equations, coefficient of regression $R^{2}$ and $F$ test results on the morphometric measurements done on Idas-like nov. sp. and Idas aff. modiolaeformis. Abbreviation: Med=Mediterranean Sea.

\begin{tabular}{|l|l|l|l|l|}
\hline & Species & Equation $\mathrm{Y}=a(\mathrm{X})^{D}$ & $R^{2}$ & $F$ test \\
\hline Marmara & Idas-like nov. sp. & $\mathrm{H}=0.6942^{*} \mathrm{~L}^{0.867}$ & 0.92 & $F=754, p<0.001$ \\
Med & Idas aff. modiolaeformis & $\mathrm{H}=0.5014^{*} \mathrm{~L}^{0.9895}$ & 0.88 & $F=527, p<0.001$ \\
\hline Marmara & Idas-like nov. sp. & $\mathrm{M}=0.16226^{*} \mathrm{~L}^{2.5526}$ & 0.91 & $F=2161, p<0.001$ \\
Med & Idas aff. modiolaeformis & $\mathrm{M}=0.1596^{*} \mathrm{~L}^{2.8893}$ & 0.93 & $F=754, p<0.001$ \\
\hline
\end{tabular}

3.3. Molecular taxonomy and phylogeny of the host

The COI mtDNA and 28S rRNA sequences were obtained from four specimens of allele, while 0 to 3 bp (mean K2P: 0.3\%) were variable among 579 bp sequenced for COI mtDNA. The COI sequences differed from those of other deep-sea mussels by K2P genetic distances ranging from $17.3 \%$ to $30.1 \%$. The phylogenetic tree (Figure 
340 fragments was consistent with the results presented by Lorion et al. (2010).

341 Specimens from the Marmara Sea clustered within the clade that includes all symbiont-bearing mussels except the genus Benthomodiolus. However, Idas-like nov. sp. could not be included into any of the lineages discussed in Lorion et al. (2010) and instead formed a long branch clustering within the multifurcation of those lineages (Figure 6). The position of Idas-like nov. sp. within the Mytilidae tree could thus not be further resolved.

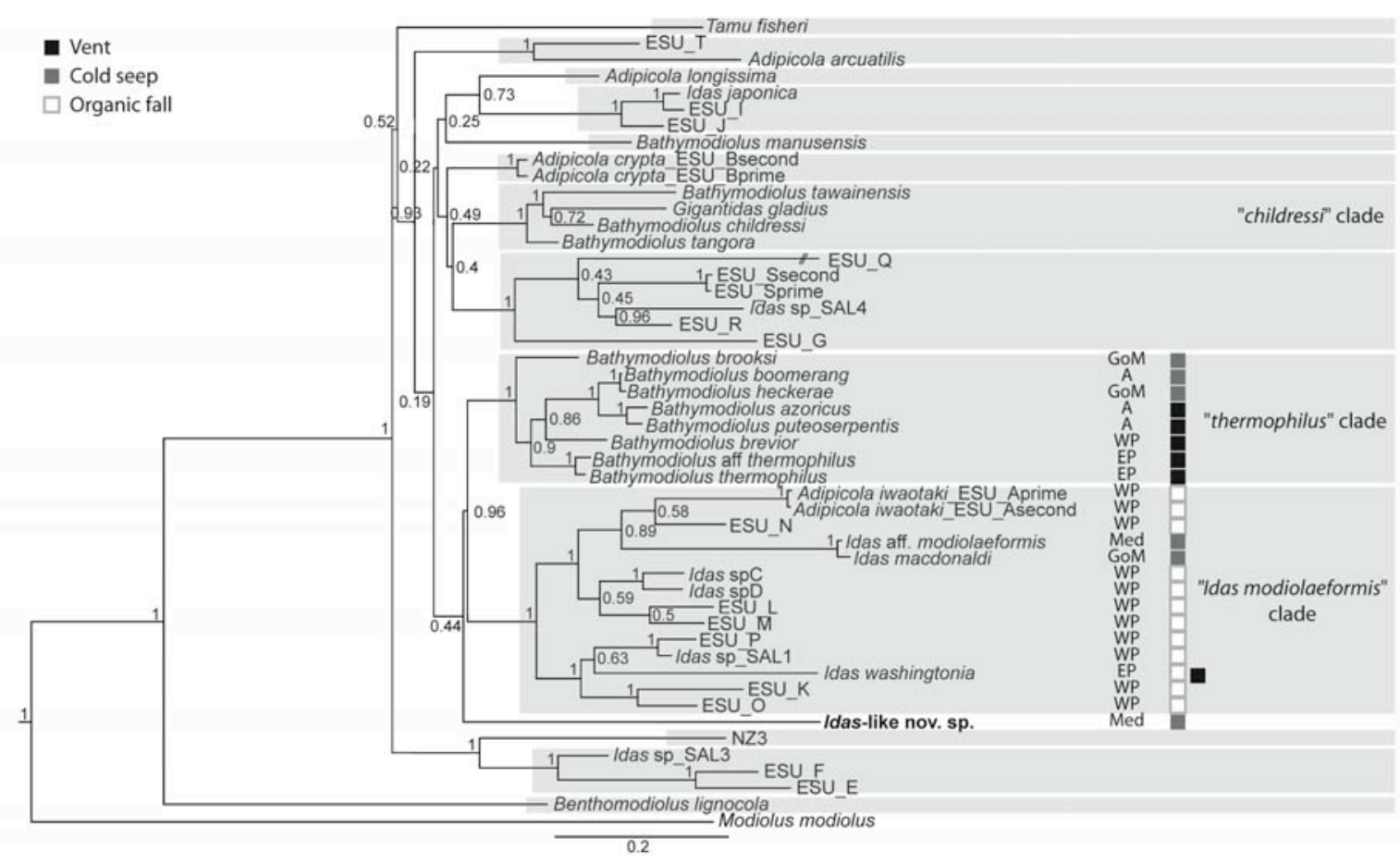

Figure 6. Maximum clade credibility phylogram obtained from Bayesian analyses of the sequences. Values above the nodes correspond to the posterior probabilities obtained from Bayesian analyses. The grey boxes correspond to lineages discussed in Lorion et al. (2010). The type of ecosystem inhabited by the species from the "thermophilus" clade and the clade including Idas aff. modiolaeformis are reported. The scale bar represents $20 \%$ estimated base substitution. Abbreviations: GoM=Gulf of Mexico, A=Atlantic, Med=Mediterranean Sea, WP=Western Pacific and $E P=$ Eastern Pacific. 
3.4. Diversity and phylogeny of associated bacteria

351 Of the 90 clones sequenced, the majority (87\%) of the sequences were affiliated with

352 the Gammaproteobacteria class, and highly similar to the sulphur-oxidising symbiont

353 of cold-seep and hydrothermal vent mussels of the genera Bathymodiolus and Idas

354 (>98\% similarity; Figure 7). The 1 base pair differences between clones are

355 potentially due to sequencing errors and therefore these sequences may represent

356 the same phylotype as the one related to mussel-associated thiotrophic symbionts

357 (Figure 7). Besides the Gammaproteobacteria, two sequences were affiliated with the

358 Epsilonproteobacteria class, three to uncultured bacteria involved in the ANaerobic 359 AMMonium OXidation reactions (or Anammox) and the last one did not have any 360 clear phylogenetic affiliation. With a coverage value of $75 \%$ for the clone library and a 361 rarefaction curve that shows saturation, it is unlikely we have missed any abundant 362 symbionts (Electronic supplementary material 1). One clone of 363 Gammaproteobacteria, the dominant phylotype, is used in the phylogenetic tree. 364 Indeed, the low clone number of other types of bacteria suggests that they represent 365 potential contaminants, free-living bacteria attached to the gills due to the filtration 366 abilities of the mussels, or some rare symbionts. 


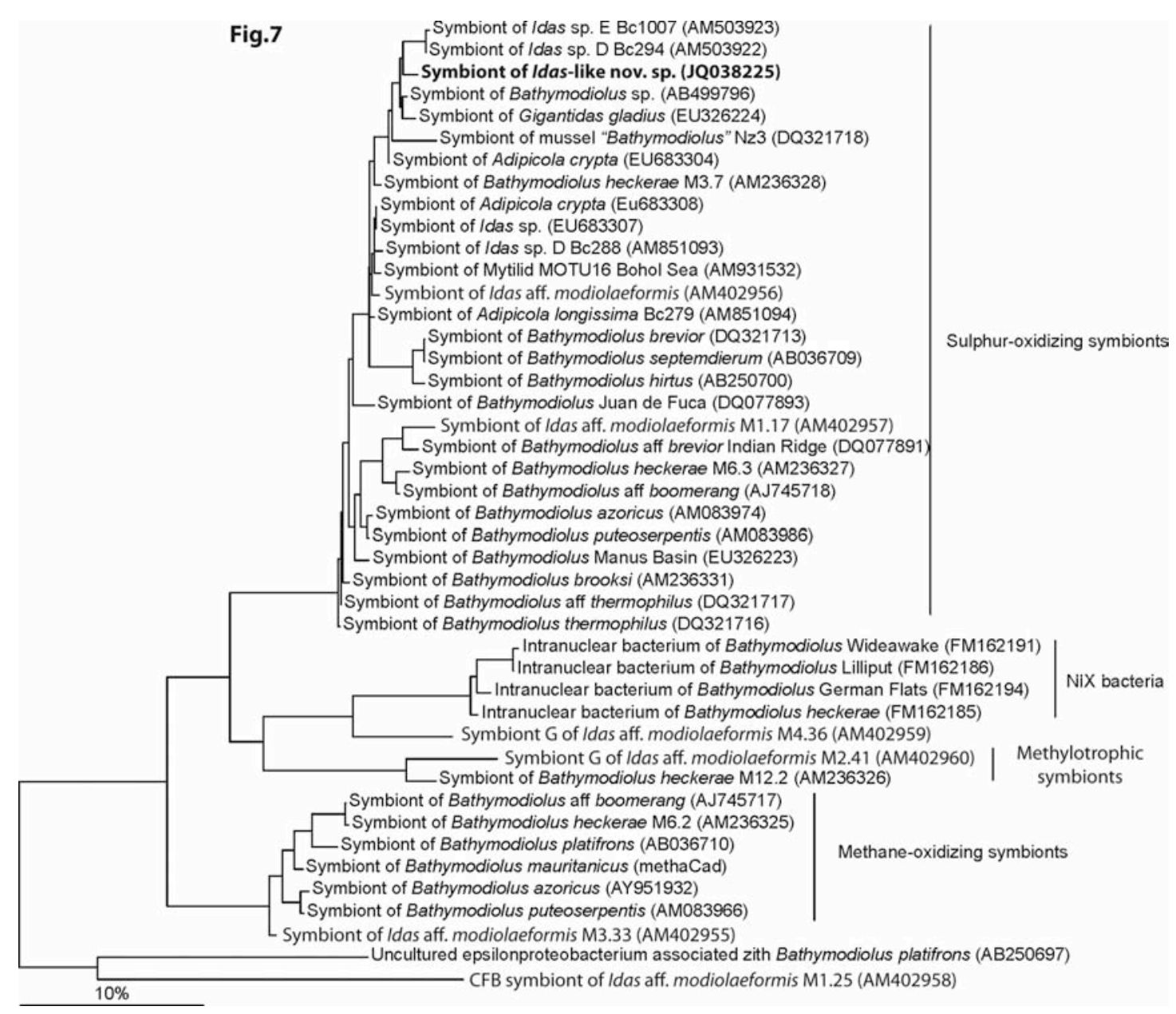

Figure 7. Phylogenetic tree displaying bacterial symbionts associated with ldas-like nov. sp. based on $16 S$ rRNA gene sequences (in bold). Bacteroidetes (CFB) and uncultured epsilonproteobacteria are used as an outgroup to the gammaproteobacteria. Posterior probabilities are displayed as percentages. Scale bar represents $10 \%$ estimated base substitution. Abbreviation: NIX: Nuclea Inclusion X.

\subsection{Localisation of associated bacteria}

370 Because the use of FISH was not anticipated, fixation and preservation of the organisms was not ideal; FISH analyses usually require gill fixation directly on board after recovery of the mussels. As a consequence, low signal intensities and good morphology (formalin-fixed tissue; Figure 8 and Electronic supplementary material 2A) or stronger signal with disrupted host cells (freezing before fixation for $\mathrm{FISH}$, Electronic supplementary material $2 \mathrm{~B}$ ) were observed. However, the combination of these results allowed reliable identification of FISH signals. Positive signals were 
observed on hybridised gill sections with probe Eub-338 targeting all bacteria (not shown) whose signal overlapped the signal observed with BangT-642 (Figure 8). We also observed a signal with probes BThio-193. Both the probes (BThio-193 and BangT-642) target known deep-sea mussel thiotrophic symbionts. The latter probe hybridised despite a one base mismatch with the identified dominant 16S rRNA phylotype, which could be explained by the moderately stringent conditions used for hybridisation (30\% formamide). Overlays of the Eub-338 and BThio-193 signals confirmed that bacteria in the gills were mostly thiotrophs. Few FISH signals were observed with the Bacteroidetes probe CF-319. Other probes, including ImedM-138 targeting methanotrophic symbionts, did not yield any signal. Despite being present in the clone library, Epsilonproteobacteria and Anammox bacteria were not detected, suggesting that these most likely represented environmental bacteria.

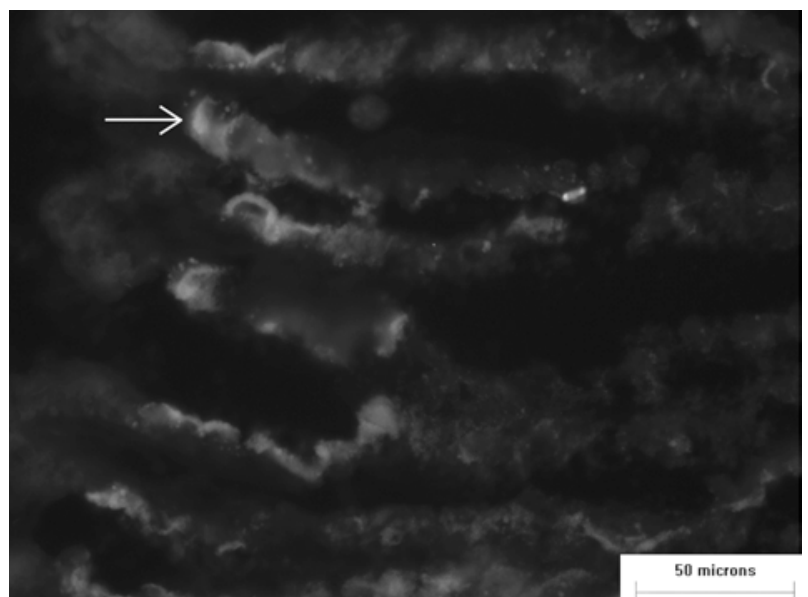

Figure 8. Fluorescence in situ hybridisation on transverse sections of gill filaments of Idas-like nov. sp. showing the distribution of thiotrophic symbiont (BangT) on the brightest part (pointed by the white arrow). Composite pictures in colour are reported in supplementary material with (A) Bang $T$ in green and Eub in red in individual $A$ and (B) Bthio in green and BangT in red in individual $B$. 


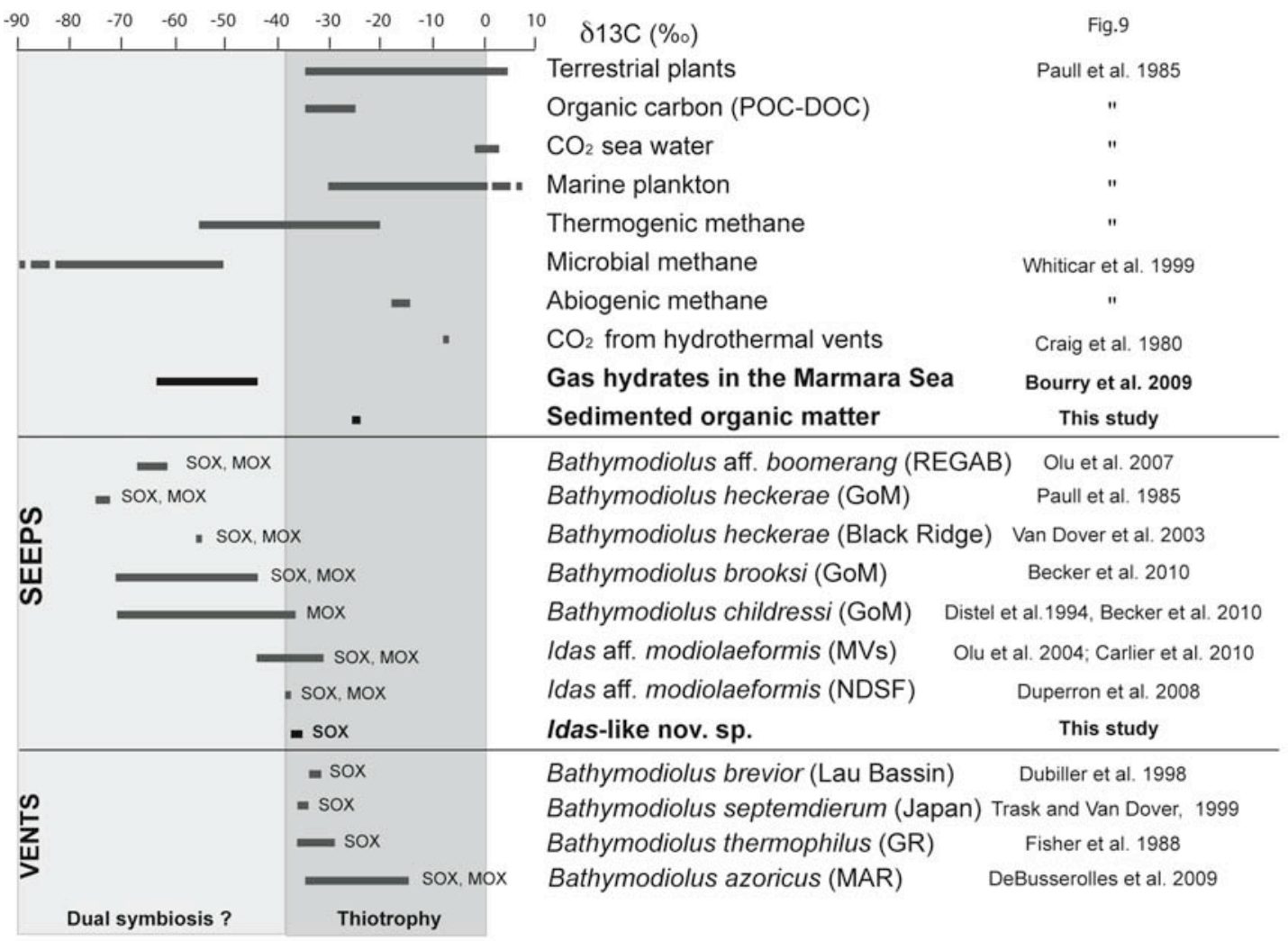

Figure $9 . \delta^{13} \mathrm{C}$ signatures of several marine and terrestrial carbon sources and a list of mussel species from vent and seep sites. Abbreviations: POC: particular organic matter, DOC: dissolved organic matter, SOX: sulphur-oxidising bacteria, MOX: methane-oxidising bacteria, GoM: Gulf of Mexico, Med: eastern Mediterranean Sea, NDSF: Nile Deep-Sea Fan, MVs: Napoli and Amsterdam mud volcanoes, GR: Galápagos ridge, MAR: Mid-Atlantic ridge. Data related to this study are highlighted in bold. 
401

402

403

404

405

406

407

408

409

410

411

412

413

414

415

416

417

418

419

420

421

422

423

424

425

\section{Discussion}

4.1. First symbiont-bearing mussel observed in the Marmara Sea: Idas-like nov. sp.

Based on both morphological and molecular data, we first assessed the systematic status of our specimens. Mitochondrial K2P genetic distances of $0.3 \%$ and the presence of a single 28S rRNA allele for all Idas-like nov. sp. individuals clearly confirmed that our specimens coming from both the Central and Tekirdağ basins of the Marmara Sea belong to a single species. Indeed, such genetic distances are well within the range of intra-specific variability previously reported in mytilid species associated with organic falls, vents and cold-seeps $(\approx 1 \%$; Lorion et al., 2010; Miyazaki et al., 2004; Won et al., 2003). Additionally, specimens from the Marmara Sea differed from all other mussels included in our tree by genetic distances above $17 \%$, such values being in the range of interspecific differences (Lorion et al., 2010). Some characters, such as length, shell and siphon shapes can be used to consistently distinguish our specimens from most species described in the Atlantic and Mediterranean Sea and also from Idas modiolaeformis (Lorion et al., 2012; Lorion et al., in press). Idas-like nov. sp., however, was morphologically very close to the largest type specimen of Idas modiolaeformis, a species that was succinctly described in the 19th century on the basis of two empty shells (Sturany, 1896). However, shell information alone has already proved irrelevant to species identification in the absence of other anatomical and/or molecular information (Lorion et al., 2010). The current study therefore further illustrates how old type specimens, which often consist of a limited number of dried empty shells, should be treated with caution when considering the taxonomy of bivalves having highly plastic shell shapes. As a consequence, it is impossible to firmly conclude whether ldas-like nov. 
sp. is a new species (Lorion et al., 2010). A complete re-assessment of the diversity of the genus Idas in the Mediterranean basins, and of all symbiont-bearing mussels worldwide, is ideally required to clarify the status of the various Idas species.

Idas-like nov. sp. represents a species that has not been previously included in molecular phylogenies. It could not be included in any of the mussel lineages reported by Lorion et al. (2010) and branched within the multifurcation that encompasses all species found at vents, seeps and organic falls. The particular history of the Mediterranean Sea nevertheless allows some inferences on its evolutionary history. It is believed that the Messinian salinity crisis eradicated most Mediterranean marine faunas between 5.33 and 5.96 million years ago and that modern Mediterranean communities reflect recent re-colonisation events (Duggen et al., 2003; Krijgsman et al., 1999; Popescu et al., 2008). In this context, the case of Idas aff. modiolaeformis is quite clear. Using a $\mathrm{COI}$ mutation rate ranging from 1 ù to $2 \%$ per million years, it appears that Idas aff. modiolaeformis diverged from its sister species Idas macdonaldi between 0.60 and 3.61million years (Lorion et al., 2012). Because Idas macdonaldi lives at cold-seeps in the Gulf of Mexico, it was suggested that the colonisation of the Mediterranean Sea occurred from the Atlantic ocean. Although a similar scenario seems a sound hypothesis to explain the occurrence of Idas-like nov. sp. in the Marmara Sea, a more resolved tree and the identification of close relatives of this species are needed to really test it properly. In any case, the high divergence between Idas-like nov. sp. and Idas aff. modiolaeformis clearly supports the hypothesis that those two species diverged a long time before they colonised the Mediterranean basins. It is striking to note that, while such highly divergent lineages of small Idas-like mussels occur in the Mediterranean basins, 
species of the "thermophilus" lineage do not, despite being phylogenetically closer to Idas aff. modiolaeformis.

Another interesting result is that Idas-like nov. sp. and Idas aff. modiolaeformis do not co-occur despite the fact that seep settings, habitat characteristics, and depth ranges at which they were collected are similar. This is surprising given that other symbiontbearing species such as the vesicomyid Isorropodon perplexum and the lucinid Lucinoma kazani have been observed at both Marmara and eastern Mediterranean Sea cold-seeps (Ritt et al., 2011; Ritt et al., 2010). Idas aff. modiolaeformis, however, has been reported in the Mediterranean cold-seep sites (Duperron et al., 2008b; Gaudonr et al. 2010; Ritt et al., 2011) but not in the Atlantic Ocean nor the western Mediterranean Sea. Furthermore, a recent study hypothesised that Idas aff. modiolaeformis may have a planktonic phase between 4 weeks to 5 months (Gaudron et al., 2012). This is unlikely that Idas-like nov. sp. or Idas aff. modiolaefomris larvae could be able to pass through the Dardanelles strait, the connection between the Marmara Sea and the Eastern Mediterranean Sea (Besiktepe et al., 1994). This barrier to dispersal could explain the different distribution of both species. However, the dispersal abilities of Idas-like nov. sp. remain to be explored as our sampling effort was restricted to a single sampling location. Further explorations of the Mediterranean and Marmara seeps are necessary to really document the reproductive strategy, dispersal abilities, and distribution, of both species.

\subsection{Life cycle}


475 The life cycle of deep-sea mytilids is still poorly known in terms of reproduction, 476 growth rates, recruitment, and larval dispersal. However, the occurrence of distinct

477

478

modes in several mussel species at deep hydrothermal vents indicates discontinuous episodes of massive larval settlement linked with discontinuous release of gametes and planktotrophic larval development (Comtet, 1994; Comtet and Desbruyères, 1998; Dixon et al., 2006; Rhoads et al., 1981; Smith et al., 2000; Van Dover et al., 1996). The same pattern has been observed at cold-seeps for Bathymodiolus childressi in the Gulf of Mexico (Arellano and Young, 2009; Nix et al., 1995; Smith et al., 2000; Tyler et al., 2007). In the present study, the size-frequency distribution exhibits a single mode. Furthermore, a high abundance of prodissoconch II postlarval stages was observed in sediments close to the sampled carbonate crusts. These prodissoconch II from the Marmara Sea are in the same range of size (450 $\mu \mathrm{m}$ ) as those of species from vents and seeps (from 380 to $520 \mu \mathrm{m}$ ), supporting the idea of a planktonic phase (Arellano and Young, 2009; Comtet et al., 2000; Gaudron et al., 2012; Lorion et al., 2012; Lorion et al., in press; Lutz et al., 1980; Lutz et al., 1984). The abundance of these post-larvae and the absence of distinctive modes suggest the presence of a continuous recruitment. Several of these larvae were dead, raising questions about the cause of this massive mortality. High recruitment rates in hydrothermal Bathymodiolus mytilids were hypothesised to balance for episodic, important mortality resulting from natural changes in hydrothermal flow and tectonic activity (Comtet and Desbruyères, 1998). Competition with adults may be another explanation of the larval mortality at our sampling site. Indeed, post-larvae may have been excluded from the hard substratum they need to settle, by the presence of adult specimens already attached on the substratum. It is hypothesised that all of the mussels within a single patch have the same age and resulted from a 
500

501

502

503

504

505

506

507

508

single recruitment event. However, our data are not sufficient to reveal the reproductive strategy or recruitment patterns of this species.

\subsection{A thiotrophic symbiosis}

Thiotrophic symbioses are well-documented for many small mytilids associated with organic falls, including various Idas species from sunken woods in the eastern Pacific (Duperron et al., 2008a). In ldas-like nov. sp., thiotrophic bacteria unambiguously dominate the populations of gill-associated symbionts. This symbiotic association resembles that of many Idas spp., but greatly differs from that occurring in Idas aff. modiolaeformis which harbours up to six distinct bacterial phylotypes, including methane- and sulphur-oxidising bacteria (Duperron et al., 2008b). Also, the thiotrophs of these two mussel species are not very closely related, an observation that is often reported in not very closely related species of mussels (Duperron et al., 2009).

Most Mytilidae from deep-sea environments live with thiotrophic bacteria and only some of them, mostly chemosynthetic ecosystems, host methanotrophic bacteria as observed in Idas aff. modiolaeformis (Duperron, 2010; Duperron et al., 2008b). In the present study it is intriguing that no methane-oxidisers were detected despite the high concentration of methane at the study area (Ritt et al., 2010). The bacteria that were only occasionally detected in Idas-like nov. sp. may either represent potential contaminants, corresponding to free-living bacteria attached to the gills, or some rare symbionts. In any case, their very low abundance suggests a limited role in the animal's nutrition. 
4.4. Nutrition

Measured carbon stable isotope signatures of Idas-like nov. sp. (from $-37.4 \%$ o to $35.5 \%$; Figure 9) were in the range of values measured in hydrothermal vent species associated exclusively with sulphur-oxidising bacteria such as Bathymodiolus thermophilus (from $-37.3 \%$ to $-29.2 \%$ ), B. septemdierum (-37\%), and B. brevior (from -35.8\% to -30.8\%;; Figure 9; Dubilier et al., 1998; Fisher et al., 1988; Trask and Dover, 1999) as well as the cold-seep species Idas modiolaeformis (-44.6\% to -38.3 \%; Carlier et al., 2010; Duperron et al., 2008a; Olu-Le Roy et al., 2004). The ${ }^{13} \mathrm{C}$ signature of Idas-like nov. sp. were higher than values from Bathymodiolus species from the Gulf of Mexico, the Blake Ridge and Western Africa, which are generally below $-37.5 \%$ and in which the symbioses involves methanotrophs, either alone or in co-occurrence with sulphur-oxidisers (Becker et al., 2010; Distel and Cavanaugh, 1994; Olu-Le Roy et al., 2007; Paull et al., 1985; Van Dover et al., 2003). Despite a limited dataset (i.e. only three measurements from a single area), our results support a chemoautotrophic-based nutrition for Idas-like nov. sp., mainly via the thiotrophic pathway. Sulphide is one of the by-products of the anaerobic oxidation of methane (AOM; Boetius et al., 2000; Carlier et al., 2010; Losekann et al., 2008). The values obtained for sedimented organic matter indicate that is a mixture of photosynthesisderived and chemoautotrophic-derived carbon, as observed in other seep sites from the Mediterranean Sea (Carlier et al., 2010). Carbon input from filter feeding cannot be excluded, as mixotrophy (i.e. symbiosis in conjunction with filter feeding and particle ingestion) has already been documented in several vent and seep Bathymodiolus species (Page et al., 1991; Page et al., 1990; Riou et al., 2010). Therefore, the carbon signatures of Idas-like nov. sp. may reflect the assimilation of various food sources including: (i) oceanic DIC, (ii) free bacteria such as 
550

551

552

553

554

555

methanotrophic or epsilonproteobacteria present in our clone libraries, (iii) surfacederived, photosynthetic carbon, and potentially (iv) some light methane-derived DIC. Nitrogen isotope ratios reflect trophic status; Idas-like nov. sp. exhibits $\delta^{15} \mathrm{~N}$ values higher than those of the sedimented organic matter, the potential food source. These relatively high $\delta^{15} \mathrm{~N}(\leq 6 \%$ ) values suggests the presence of chemoautotrophic symbionts. They are close to the limit established by Levin and Michener (2002) for species with symbionts. They also suggest the utilisation of organic matter from photosynthetic origin as suggested by the $\delta^{13} \mathrm{C}$.

\subsection{Conclusion}

Here we present the first description of a thiotrophic mussel species, Idas-like nov. sp., associated with cold-seep deep-sea ecosystems in the Marmara Sea. Based on morphological characters of empty shells, we cannot firmly conclude that Idas-like nov. sp. is different from Idas modiolaeformis (Sturany, 1896) of the eastern Mediterranean Sea. However, according to molecular data ldas-like nov. sp. branches separately in phylogenetic reconstructions, far from any other documented "Bathymodiolus" and "Idas" suggesting that (1) it represents a new lineage and, (2) it diverged from Idas aff. modiolaeformis long before both species colonised the Mediterranean Sea seeps.

As well as molecular and morphological differences, both Idas species also present distinct types of symbiotic association. Idas-like nov. sp. harbours thiotrophic symbionts in its gills, a symbiosis comparable to that described in several small mussels from organic falls and vents (Duperron, 2010; Duperron et al., 2009), while Idas aff. modiolaeformis has six symbiont types. No methanotroph was found in the 
575 Marmara Sea species despite the presence of methane-enriched fluids (Ritt et al., 576 2010). However further analyses on a higher number of individuals is needed to 577 define whether the SOX bacteria are truly the only type, or at least the very dominant 578 type of symbionts living within Idas-like nov. sp. gills. Questions about the ability of 579 this symbiotic species to cope with its seep environment, and the exact role of the 580 symbionts in host nutrition compared to other potential sources, remain to be elucidated.

582

5. Acknowledgements

584

Captain and crew of R/V Atalante as well as Nautile's pilots are warmly 586 acknowledged for their dedicated assistance and for their contribution to the success of the cruise, especially during the dives 1644 and 1665. The chief scientist of MarNaut was Pierre Henry. We thank Clara Rodrigues and Antoine Carlier for their help with the stable isotope analyses and Dr. Erick Cordes for helpful comments to improve the manuscript. We also thank the anonymous reviewers for their reasoned annotations that have help the manuscript to gain in clarity and logic. The mytilid pictures were performed by Patrick Briand and Philippe Crassous (SEM). BR's thesis was entirely funded by the French Institute for the Exploitation of the Sea (Ifremer). This research project benefited from funds from HERMES and HERMIONE European projects (Contracts \#511234 and \#226354) as well as ANR DEEP-OASES (ANR06BDV005) and from support from the GDR ECCHIS. 
601

602

603

604

605

606

607

608

609

610

611

612

613

614

615

616

617

618

619

620

621

622

623

624

625

626

627

628

629

630

631

632

633

634

635

636

637

638

639

640

641

642

643

644

645

646

647

648

649

650

Altschul, S.F., Gish, W., Miller, W., Myers, E.W., Lipman, D.J., 1990. Basic local alignment search tool. Journal of Molecular Biology 215 (3), 403-410.

Amann RI, Binder BJ, Olson RJ, Chisholm SW, Devereux R, Stahl DA (1990) Combination of 16 s ribosomal-RNA-targeted oligonucleotide probes with flow-cytometry for analyzing mixed microbial-populations. Appl Environ Microbiol 56 (6à:1919-1925.

Arellano, S.M., Young, C.M., 2009. Spawning, development, and the duration of larval life in a deep-sea cold-seep mussel. Biological Bulletin 216 (2), 149-162.

Baker, A.M., Bartlett, C., Bunn, S.E., Goudkamp, K., Sheldon, F., Hughes, J.M., 2003. Cryptic species and morphological plasticity in long-lived bivalves (Unionoida : Hyriidae) from inland Australia. Molecular Ecology 12 (10), 2707-2717.

Bayon, G., Loncke, L., Dupre, S., Ducassou, E., Duperron, S., Etoubleau, J., Foucher, J.P., Fouquet, Y., Gontharet, S., Huguen, C., Klaucke, I., Mascle, J., Olu-Le Roy, K., Ondreas, H., Pierre, C., Sibuet, M., Stadnitskaia, A., Woodside, J., 2009. Multi-discinplinary investigations of fluid seepage on an unstable margin: The case of the Central Nile deep sea fan. Marine Geology 261 (1-4), 92.104.

Becker, E.L., Lee, R.W., Macko, S.A., Faure, B.M., Fisher, C.R., 2010. Stable carbon and nitrogen isotope compositions of hydrocarbon-seep bivalves on the Gulf of Mexico lower continental slope. Deep Sea Research Part II: Topical Studies in Oceanography 53 (21-23), 1957-1964.

Besiktepe, S.T., Sur, H.I., Ozsoy, E., Latif, M.A., Oguz, T., Unluata, U., 1994. The circulation and hydrography of the Marmara Sea. Progress In Oceanography 34 (4), 285-334.

Bhattacharya, C.G., 1967. A simple method of resolution of a distribution into Gaussian components. Biometrics 23 (1), 115-135.

Boetius, A., Ravenschlag, K., Schubert, C.J., Rickert, D., Widdel, F., Gieseke, A., Amann, R., Jorgensen, B.B., Witte, U., Pfannkuche, O., 2000. A marine microbial consortium apparently mediating anaerobic oxidation of methane. Nature 407 (6804), 623-626.

Bourry C, Chazallon B, Charlou JL, Pierre Donval J, Ruffine L, Henry P, Geli L, Çagatay MN, Inan S, Moreau M (2009) Free gas and gas hydrates from the Sea of Marmara, Turkey: Chemical and structural characterization. Chemical Geology 264:197-206

Carlier, A., Ritt, B., Rodrigues, C., Sarrazin, J., Olu, K., Grall, J., Clavier, J., 2010. Heterogeneous energetic pathway and carbon sources for deep earstern Mediterranean cold-seep communities. Marine Biology 157, 2545-2565.

Cavanaugh, C.M., 1983. Symbiotic chemoautotrophic bacteria in marine-invertebrates from sulfide-rich habitats. Nature 302 (5903), 58-61.

Comtet, T., 1994. Etude de la croissance allométrique et de la structure de modioles sur la zone hydrothermale Lucky Strike $\left(37^{\circ} 17^{\prime} \mathrm{N}\right.$ sur la ride médio-atlantique), Université de Bretagne Occidentale, Brest.

Comtet, T., Desbruyères, D., 1998. Population structure and recruitment in mytilid bivalves from the Lucky Strike and Menez Gwen hydrothermal vent fields $\left(37^{\circ} 17^{\prime} \mathrm{N}\right.$ and $37^{\circ} 50^{\prime} \mathrm{N}$ on the Mid-Atlantic Ridge). Marine Ecology Progress Series 163, 165-177.

Comtet, T., Jollivet, D., Khripounoff, A., Segonzac, M., Dixon, D.R., 2000. Molecular and morphological identification of settlement-stage vent mussel larvae, Bathymodiolus azoricus (Bivalvia : Mytilidae), preserved in situ at active vent fields on the Mid-Atlantic Ridge. Limnology And Oceanography 45 (7), 1655-1661.

Craig, H., Welhan, J.A., Kim, K., Poreda, R., Lupton,J .E., 1980. Geochemicalstudiesof the 21degrees N EPR hydrothermal fluids. Trans. Am.Geophys.Union 61, 992.

Dautzenberg, P., 1927. Mollusques provenant des campagnes scientifiques du Prince Albert ler de Monaco dans I'Océan Atlantique et dans le Golfe de Gascogne. Résultats des campagnes scientifiques accomplies sur son yacht par Albert ler Prince souverain de Monaco 72, 1-400, pls 401-409. 
De Busserolles, F., Sarrazin, J., Gauthier, O., Gélinas, Y., Fabri, M.C., Sarradin, P.M., Desbruyères, D., 2009. Are spatial variations in the diets of hydrothermal fauna linked to local environmental conditions? Deep Sea Res. Part II 56 (19-20), 1649-1664.

Distel, D.L., Baco, A.R., Chuang, E., Morrill, W., Cavanaugh, C., Smith, C.R., 2000. Marine ecology - Do mussels take wooden steps to deep-sea vents? Nature 403 (6771), 725-726.

Distel, D.L., Cavanaugh, C.M., 1994. Independent phylogenetic origins of methanotrophic and chemoautotrophic bacterial endosymbioses in marine bivalves. Journal of Bacteriology $176(7), 1932-1938$.

Dixon, D.R., Lowe, D.M., Miller, P.I., Villemin, G.R., Colaço, A., Serrao-Santos, R., Dixon, L.R.J., 2006. Evidence of seasonal reproduction in the Atlantic vent mussel Bathymodiolus azoricus, and an apparent link with the timing of photosynthetic primary production. Journal of Marine Biological Association of the United Kingdom 86 (6), 1363-1371.

Drummond, A., Rambaut, A., 2007. BEAST: Bayesian evolutionary analysis by sampling trees. BMC Evolutionary Biology 7 (1), 214.

Dubilier, N., Bergin, C., Lott, C., 2008. Symbiotic diversity in marine animals: the art of harnessing chemosynthesis. Nature Reviews Microbiology 6 (10), 725-740.

Dubilier, N., Windoffer, R., Giere, O., 1998. Ultrastructure and stable carbon isotope composition of the hydrothermal vent mussels Bathymodiolus brevior and $B$. sp. affinis brevior from the North Fiji Basin, western Pacific. Marine Ecology Progress Series 165, $187-$ 193.

Duggen, S., Hoernle, K., van den Bogaard, P., Rüpke, L., Morgan, J.P., 2003. Deep roots of the Messinian salinity crisis. Nature 422 (6932), 602-606.

Duperron, S., 2010. The Diversity of Deep-Sea Mussels and Their Bacterial Symbioses. In: Kiel, S. (Ed.), The Vent and Seep Biota. Springer Netherlands, pp. 137-167.

Duperron, S., Laurent, M.C.Z., Gaill, F., Gros, O., 2008a. Sulphur-oxidizing extracellular bacteria in the gills of Mytilidae associated with wood falls. FEMS Microbiology Ecology 63 (3), 338-349.Duperron, S., Lorion, J., Samadi, S., Gros, O., Gaill, F., 2009. Symbioses between deep-sea mussels (Mytilidae: Bathymodiolinea) and chemosynthetic bacteria: diversity, function and evolution. Comptes Rendus Biologies 332 (2-3), 298-310.

Duperron, S., Halary, S., Lorion, J., Sibuet, M., Gaill, F., 2008b. Unexpected co-occurrence of six bacterial symbionts in the gills of the cold seep mussel ldas sp (Bivalvia: Mytilidae). Environmental Microbiology 10 (2), 433-445.

Duperron S, Lorion J, Samadi S, Gros O, Gaill F (2009) Symbioses between deep-sea mussels (Mytilidae: Bathymodiolinea) and chemosynthetic bacteria: diversity, function and evolution. Comptes Rendus Biologies 332:298-310.

Duperron S, Lorion J, Samadi S, Gros O, Gaill F (2009) Symbioses between deep-sea mussels (Mytilidae: Bathymodiolinea) and chemosynthetic bacteria: diversity, function and evolution. Comptes Rendus Biologies 332:298-310.

Duperron, S., Nadalig, T., Caprais, J.-C., Sibuet, M., Fiala-Medioni, A., Amann, R., Dubilier, N., 2005. Dual symbiosis in a Bathymodiolus sp. mussel from a methane seep on the Gabon continental margin (Southeast Atlantic): 16S rRNA phylogeny and distribution of the symbionts in gills. Applied And Environmental Microbiology 71 (4), 1694-1700.

Felbeck, H., Childress, J.J., Somero, G.N., 1981. Calvin-Benson cycle and sulphide oxidation enzymes in animals from sulphide-rich habitats. Nature 293 (5830), 291-293.

Felsenstein, J., 1989. PHYLIP - Phylogeny Inference Package (Version 3.2). Cladistics 5, 164-166.

Fisher, C.R., 1990. Chemoautotrophic and methanotrophic symbioses in marineinvertebrates. Reviews In Aquatic Sciences 2 (3-4), 399-436.

Fisher, C.R., Childress, J.J., Arp, A.J., Brooks, J.M., Distel, D., Favuzzi, J.A., Felbeck, H., Hessler, R., Johnson, K.S., Kennicutt li, M.C., Macko, S.A., Newton, A., Powell, M.A., Somero, G.N., Soto, T., 1988. Microhabitat variation in the hydrothermal vent mussel, Bathymodiolus thermophilus, at the Rose Garden vent on the Galapagos Rift. Deep Sea Research Part I. Oceanographic Research Papers 35 (10-11), 1769-1791. 
Gaudron, S.M., Demoyencourt, E., Duperron, S., 2012. Reproductive traits of the cold-seep symbiotic mussel Idas modiolaeformis: Gametogenesis and larval biology. Biological Bulletin $222(1), 6-16$.

Gaudron, S.M., Pradillon, F., Pailleret, M., Duperron, S., Le Bris, N., Gaill, F., 2010. Colonization of organic substrates deployed in deep-sea reducing habitats by symbiotic species and associated fauna. Marine Environmental Research 70 (1), 1-12.

Gustafson, R.G., Turner, R.D., Lutz, R.A., Vrijenhoek, R.C., 1998. A new genus and five new species of mussels (Bivalvia, Mytilidae) from deep-sea sulfide/hydrocarbon seeps in the Gulf of Mexico. Malacologia 40 (1-2), 63-112.

Hall, T.A., 1999. BioEdit: a user-friendly biological sequence alignment editor and analysis program for Windows 95/98/NT. Nucleic Acids Symposium Series 41, 95-98.

Huguen C, Foucher JP, Mascle J, Ondreas H, Thouement M, Stadnitskaia A, Pierre C, Bayon G, Loncke L, Boetius A, Bouloubassi I, De Lange G, Caprais JC, Fouquet $\mathrm{Y}$, Woodside J, Dupre S, and the NAUTINIL Scientific Party (2009) Menes Caldera, a highly active site of brine seepage in the Eastern Mediterranean Sea: "In situ" observations from the NAUTINIL expedition (2003) Marine Geology 261:138-152.

Huxley, J.S., Teissier, G., 1936. Terminology of relative growth. Nature 137, 780-781.

Jeffreys, J.G., 1876. New and peculiar Mollusca of the Pecten, Mytilus, and Arca families procured in the "Valorous" expedition. Annals and Magazine of Natural History (4) 18 (107), 424-436.

Keen, A.M., 1958. Sea shells of tropical west America. Stanford University Press Stanford. Kenk, V.C., Wilson, B.R., 1985. A new mussel (Bivalvia, Mytilidae) from hydrothermal vents in the Galapagos Rift zone. Malacologia 26 (1-2), 253-272.

Krijgsman, W., Hilgen, F.J., Raffi, I., Sierro, F.J., Wilson, D.S., 1999. Chronology, causes and progression of the Messinian salinity crisis. Nature 400 (6745), 652-655.

Levin, L.A., 2005. Ecology of cold seep sediments: Interactions of fauna with flow, chemistry and microbes. Oceanography And Marine Biology - An Annual Review. Crc Press-Taylor \& Francis Group, Boca Raton, pp. 1-46.

Lorion, J., Buge, B., Cruaud, C., Samadi, S., 2010. New insights into diversity and evolution of deep-sea Mytilidae (Mollusca: Bivalvia). Molecular Phylogenetics and Evolution 57 (1), 7183.

Lorion, J., Duperron, S., Gros, O., Cruaud, C., Samadi, S., 2009. Several deep-sea mussels and their associated symbionts are able to live both on wood and on whale falls. Proceedings of the Royal Society B-Biological Sciences 276 (1654), 177-185.

Lorion, J., Halary, S., do Nasciment, J., Samadi, S., Couloux, A., Duperron, S., 2012. Evolutionary history of Idas sp Med (Bivalvia: Mytilidae), a cold seep mussel bearing multiple symbionts. Cahiers De Biologie Marine 53 (1), 77-87.

Lorion, J., Halary, S., do Nascimento, J., Samadi, S., Couloux, A., Duperron, S., in press. Evolutionary history of Idas sp. Med, (Bivalvia: Mytilidae), a cold seep mussel bearing multiple symbionts. Cahiers De Biologie Marine.

Lorion, J., Samadi, S., 2010. Species richness, sampling bias and phylogenetics in deep-sea mussels. Cahiers De Biologie Marine 51 (4), 435-439.

Losekann, T., Robador, A., Niemann, H., Knittel, K., Boetius, A., Dubilier, N., 2008. Endosymbioses between bacteria and deep-sea siboglinid tubeworms from an Arctic cold seep (Haakon Mosby Mud Volcano, Barents Sea). Environmental Microbiology 10 (12), 3237-3254.

Lutz, R.A., Jablonski, D., Rhoads, D.C., Turner, R.D., 1980. Larval dispersal of a deep-sea hydrothermal vent bivalve from the Galápagos Rift. Marine Biology 57 (2), 127-133.

Lutz, R.A., Jablonski, D., Turner, R.D., 1984. Larval development and Ddispersal at deepsea hydrothermal vents. Science 226 (4681), 1451-1454.

Manz W, Amann R, Ludwig W, Wagner M, Schleifer KH (1992) Phylogenetic oligodeoxynucleotide probes for the major subclasses of Proteobacteria - Problems and solutions. Systematic and Applied Microbiology 15:593-600. 
Manz W, Amann R, Ludwig W, Vancanneyt M, Schleifer KH (1996) Application of a suite of 16S rRNA-specific oligonucleotide probes designed to investigate bacteria of the phylum cytophaga-flavobacter-bacteroides in the natural environment. Microbiology-(UK) 142:10971106.

Marshall , J.T., 1900. On a British species of Myrina with a note on the genus Idas. Journal of Malacology 7 (7), 167-170.

Miyazaki, J.I., Martins, L.D., Fujita, Y., Matsumoto, H., Fujiwara, Y., 2010. Evolutionary Process of Deep-Sea Bathymodiolus Mussels. PLoS ONE 5 (4), 11.

Miyazaki, J.I., Shintaku, M., Kyuno, A., Fujiwara, Y., Hashimoto, J., Iwasaki, H., 2004. Phylogenetic relationships of deep-sea mussels of the genus Bathymodiolus (Bivalvia: Mytilidae). Marine Biology 144 (3), 527-535.

Nix, E., Fisher, C.R., Vodenichar, J., Scott, K.M., 1995. Physiological ecology of a mussel with methanotrophic endosymbionts at three hydrocarbon seep sites in the Gulf of Mexico. Marine Biology 122 (4), 605-617.

Olu-Le Roy, K., Caprais, J.C., Fifis, A., Fabri, M.C., Galeron, J., Budzinsky, H., Le Menach, K., Khripounoff, A., Ondreas, H., Sibuet, M., 2007. Cold-seep assemblages on a giant pockmark off West Africa: spatial patterns and environmental control. Marine Ecology-An Evolutionary Perspective 28 (1), 115-130.

Olu-Le Roy, K., Sibuet, M., Fiala-Medioni, A., Gofas, S., Salas, C., Mariotti, A., Foucher, J.P., Woodside, J., 2004. Cold seep communities in the deep eastern Mediterranean Sea: composition, symbiosis and spatial distribution on mud volcanoes. Deep Sea Research Part I: Oceanographic Research Papers 51 (12), 1915-1936.

Page, H.M., Fiala-Medioni, A., Fisher, C.R., Childress, J.J., 1991. Experimental evidence for filter-feeding by the hydrothermal vent mussel, Bathymodiolus thermophius. Deep-Sea Research Part I-Oceanographic Research Papers 38 (12), 1455-1461.

Page, H.M., Fisher, C.R., Childress, J.J., 1990. Role of filter-feeding in the nutritional biology of a deep-sea mussel with methanotrophic symbionts. Marine Biology 104 (2), 251-257.

Paull, C.K., Jull, A.J.T., Toolin, L.J., Linick, T., 1985. Stable isotope evidence for chemosynthesis in an abyssal seep community. Nature 317 (6039), 709-711.

Pelorce, J., Poutiers, J.-M., 2009. Une nouvelle espèce de Bathymodiolinae (Mollusca, Bivalvia, Mytilidae) associée à des os de baleine coulés en Méditerranée. Zoosystema 31 (4), 975-985.

Popescu, S.M., Melinte, M.C., Suc, J.P., Clauzon, G., Quillevere, F., Sütö-Szentai, M., 2008. Marine reflooding of the Mediterranean after the Messinian salinity crisis predates the Zanclean GSSP. Geobios 41 (5), 657-660.

Pruesse, E., Quast, C., Knittel, K., Fuchs, B.M., Ludwig, W., Peplies, J., Glöckner, F.O., 2007. SILVA: a comprehensive online resource for quality checked and aligned ribosomal RNA sequence data compatible with ARB. Nucleic Acids Research 35 (21), 7188-7196.

Rhoads, D.C., Lutz, R.A., Revelas, E.C., Cerrato, R.M., 1981. Growth of bivalves at deepsea hydrothermal vents along the Galapagos rift. Science 214 (4523), 911-913.

Riou, V., Colaco, A., Bouillon, S., Khripounoff, A., Dando, P., Mangion, P., Chevalier, E., Korntheuer, M., Santos, R.S., Dehairs, F., 2010. Mixotrophy in the deep sea: a dual endosymbiotic hydrothermal mytilid assimilates dissolved and particulate organic matter. Marine Ecology-Progress Series 405, 187-201.

Ritt, B., Pierre, C., Gauthier, O., Wenzhöfer, F., Boetius, A., Sarrazin, J., 2011. Diversity and distribution of cold-seep fauna associated with different geological and environmental settings at mud volcanoes and pockmarks of the Nile Deep-Sea Fan. Marine Biology 158 (6), 1187-1210.

Ritt, B., Sarrazin, J., Caprais, J.-C., Noël, P., Gauthier, O., Pierre, C., Henry, P., Desbruyères, D., 2010. First insights into the structure and environmental setting of coldseep communities in the Marmara Sea. Deep Sea Research Part I: Oceanographic Research Papers 57 (9), 1120-1136. 
Samadi, S., Quemere, E., Lorion, J., Tillier, A., von Cosel, R., Lopez, P., Cruaud, C., Couloux, A., Boisselier-Dubayle, M.C., 2007. Molecular phylogeny in mytilids supports the wooden steps to deep-sea vents hypothesis. Comptes Rendus Biologies 330 (5), 446-456. Sibuet, M., Olu, K., 1998. Biogeography, biodiversity and fluid dependence of deep-sea coldseep communities at active and passive margins. Deep Sea Research Part II: Topical Studies in Oceanography 45 (1-3), 517-567.

Singleton, D.R., Furlong, M.A., Rathbun, S.L., Whitman, W.B., 2001. Quantitative comparisons of $16 \mathrm{~S}$ rRNA gene sequence libraries from environmental samples. Applied And Environmental Microbiology 67 (9), 4374-4376.

Smith, E.B., Scott, K.M., Nix, E.R., Korte, C., Fisher, C.R., 2000. Growth and condition of seep mussels (Bathymodiolus childressi) at a Gulf of Mexico brine pool. Ecology 81 (9), 2392-2403.

Sturany, R., 1896. Zoologische Ergebnisse VII. Mollusken I (Prosobranchier und Opisthobranchier; Scaphopoden; Lamellibranchier) gesammelt von S.M. Schiff "Pola" 189018. Denkschriften der Kaiserlichen Akademie der Wissenschaften, MathematischeNaturwissenschaftlischen Classe 63, 1-36.

Tamura, K., Dudley, J., Nei, M., Kumar, S., 2007. MEGA4: Molecular Evolutionary Genetics Analysis (MEGA) Software Version 4.0. Molecular Biology and Evolution 24 (8), 1596-1599.

Trask, J.L., Dover, C.L.V., 1999. Site-specific and ontogenetic variations in nutrition of mussels (Bathymodiolus sp.) from the Lucky Strike Hydrothermal vent field, Mid-Atlantic Ridge. Limnology And Oceanography 44 (2), 334-343.

Tyler, P., Young, C.M., Dolan, J., Arellano, S.M., Brooke, S.D., Baker, E.T., 2007. Gametogenic periodicity in the chemosynthetic cold-seep mussel "Bathymodiolus" childressi. Marine Biology 150 (5), 829-840.

Van Dover, C.L., Aharon, P., Bernhard, J.M., Caylor, E., Doerries, M., Flickinger, W., Gilhooly, W., Goffredi, S.K., Knick, K.E., Macko, S.A., Rapoport, S., Raulfs, E.C., Ruppel, C., Salerno, J.L., Seitz, R.D., Sen Gupta, B.K., Shank, T., Turnipseed, M., Vrijenhoek, R., 2003. Blake Ridge methane seeps: characterization of a soft-sediment, chemo synthetically based ecosystem. Deep-Sea Research Part I-Oceanographic Research Papers 50 (2), 281-300.

Van Dover, C.L., Desbruyères, D., Segonzac, M., Comtet, T., Saldanha, L., Fiala-Medioni, A., Langmuir, C., 1996. Biology of the Lucky Strike hydrothermal field. Deep Sea Research Part I: Oceanographic Research Papers 43 (9), 1509-1529.

Von Cosel , R., Marshall, B.A., 2010. A new genus and species of large mussel (Mollusca: Bivalvia: Mytilidae) from the Kermadec Ridge. Tuhinga (21), 59-73.

Von Cosel, R., Olu, K., 1998. Gigantism in Mytilidae. A new Bathymodiolus from cold seep areas on the Barbados accretionary prism. Comptes Rendus De L'Academie Des Sciences Serie III-Sciences De La Vie-Life Sciences 321 (8), 655-663.

Warén, A., Carrozza, F., 1990. Idas ghisottii sp.n., a new mytilid bivalve associated with sunken wood in the Mediterranean. Bollettino Malacologico 26 (1-4), 19-24.

Whiticar, M.J., 1999. Carbon and hydrogen isotope systematics of bacterial formation and oxidation of methane. Chem. Geol. 161 (1-3), 291-314.

Won, Y., Young, C.R., Lutz, R.A., Vrijenhoek, R.C., 2003. Dispersal barriers and isolation among deep-sea mussel populations (Mytilidae : Bathymodiolus) from eastern Pacific hydrothermal vents. Molecular Ecology 12 (1), 169-184. 


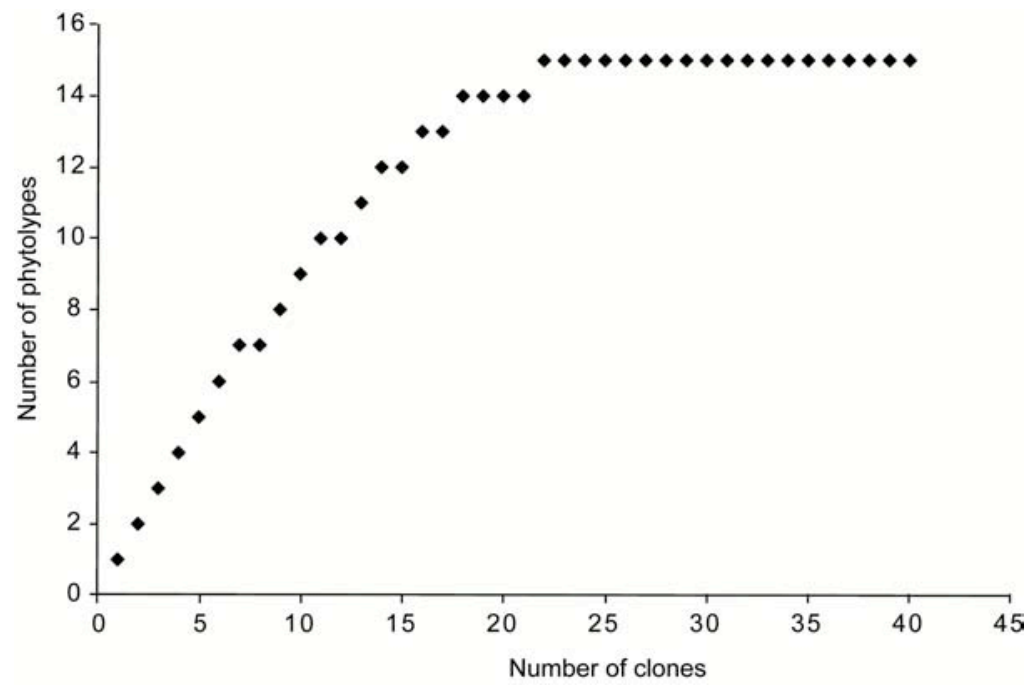

Electronical supplementary 1. Rarefaction analysis of the overall, combined bacterial 16S rRNA gene clone library recovered from gills of the Idas-like nov. sp. Marmara specimen. The rarefaction curve, plotting the number of observed phylotypes as a function of the number of clones, was computed by estimates. 

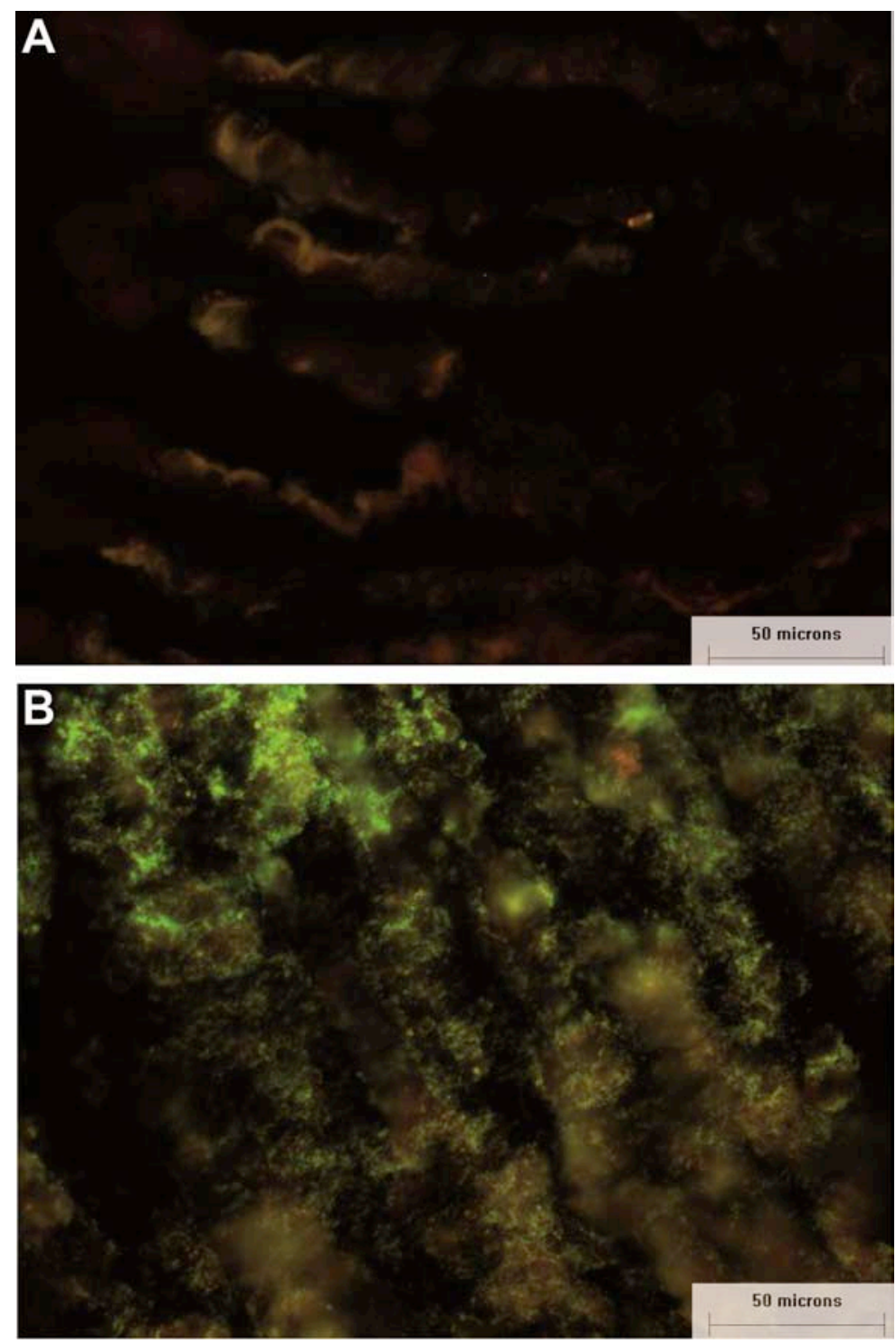

Electronical supplementary 2. Fluorescence in situ hybridization on transversal sections of gill filaments of a ldas-like nov. sp. (A) Composite picture showing the distribution of thiotrophic symbionts in green (BangT) and Eubacteria in red in the individual A. (B) Composite picture showing the distribution of two types of thiotrophic symbionts in green (Bthio) and in red (BangT) in the individual $B$. Differences in the quality of the signal (favoured in $B$ ) and in the preservation of the gill ultra-structure (favoured in A) is noticeable. 